\title{
Roman en film - stories in woorde en beelde 'n Voorstel vir'n gevorderde kursus in literatuurwetenskap
}

\begin{abstract}
In this article a course in narratology, in which the emphasis falls on films based on specific novels, is discussed. The article is mainly informative, giving details about the principles on which the course is based, explaining the way in which the course was developed and outlining the contents of the course. In the last part of the article three examples of the approach which is followed are given and the bibliography can be seen as a basic reading list for such a course. The article is an empirical report which puts forward a possible way in which the study of films on an advanced level can be approached.
\end{abstract}

\section{Inleiding}

In hierdie artikel word aangetoon hoe 'n universiteitskursus waarin films bestudeer word, daar sou kon uitsien. Die belangrikheid van die film as een van die magtigste, gewildste en mees prominente vorms van kommunikasie en vermak in ons tyd, maak die studie van films nie net relevant nie, maar selfs noodsaaklik.

Die wetenskaplike bestudering van films is nog nie 'n algemene verskynsel aan SuidAfrikaanse universiteite nie, hoewel daar wel in departemente Kunsgeskiedenis en in Kommunikasiekunde aandag gegee word aan relevante aspekte van films soos die film as beeldende kunsvorm of die film as kommunikasiemedium. Daar word ook aan die tegniese aspekte van filmproduksie aandag gegee in sowel Kommunikasiekunde as Kunsgeskiedenis.

Die insluiting van 'n kursus wat onder meer fokus op films is egter 'n heel logiese uitvloeisel van die moontlikhede van die kontemporêre literatuurwetenskap en spesifiek van die narratologie as dissipline. Die afgelope paar jaar kan studente 'n kursus genaamd Roman en film volg as een van die vyf kursusse wat vereis word vir die Honneurskursus in Algemene Taal- en Literatuurwetenskap aan die Potchefstroomse Universiteit. Die kursus kan ook gevolg word deur studente wat 'n Honneurs-kursus in Afrikaans en Nederlands of Engels loop.

In hierdie artikel gaan ek eers die aanbieding van 'n kursus oor romans en films binne 'n 
departement Algemene Taal- en Literatuurwetenskap motiveer. Daarna gaan die ontwikkeling van die kursus beskryf word. Die inhoud van die kursus word vervolgens kortliks uiteengesit en 'n illustrasie van die werkwyse word aan die hand van enkele voorbeelde gedoen.

Die bibliografie aan die einde van die artikel dui nie net die bronne aan waarna in die artikel verwys word nie, maar bevat 'n lys van die belangrikste bronne wat studente in die kursus kan gebruik. Die bibliografie word vanselfsprekend deur die studente uitgebrei deur selfstudie en navorsing met die oog op referate. Die bibliografie aan die einde van die artikel word ingedeel in vier kategorieë. Die primêre bronne waarna die artikel verwys, word eers apart aangedui. Dan volg die basiese literêr-teoretiese bronne wat gebruik word (waarin die klem val op die narratologie), die bronne wat handel oor filmteorie en filmgeskiedenis en die vierde groep bevat sekondere bronne wat hoofsaaklik bestaan uit teksstudies van die werke waarna die artikel verwys.

Die artikel is hoofsaaklik 'n informatiewe stuk waarin bepaalde moontlikhede vir 'n Honneurs-kursus aan die orde gestel word. Omdat kursusbeplanning en -ontwikkeling nooit afgehandel is nie, is dit vanselfsprekend dat die voorstel onderhewig is aan verandering en dat dit in hierdie stadium steeds baie leemtes vertoon. Die kursus word van jaar tot jaar aangepas om tred te hou met nuwe beskikbare tekste en teoretiese ontwikkelinge, maar is tog 'n poging om 'n begin te maak met die teoretiese bestudering van die filmmedium op 'n gevorderde vlak.

\section{Motivering van 'n kursus Roman en film}

\subsection{Algemene motivering}

Die narratologie word omskryf as die teorie van verhalende tekste, of anders gestel die studie van die vorm en funksie van verhalende tekste (Bal,1980:12; Prince,1982:4; Du Plooy, 1986:275,278). Hierdie aanvanklike omskrywings van die dissipline het dit duidelik gestel dat alle verhalende tekste en alle soorte verhalende tekste binne die narratologie bestudeer kan word. Die moontlikheid van interdissiplinère studies binne die narratologie is een van die aantreklikste aspekte van dié dissipline.

Soos wat die literêre teorie oor die afgelope twintig tot dertig jaar ontwikkel het, het die narratologie tred gehou sodat verhalende tekste vanuit verskillende teoretiese invalshoeke bestudeer kan word, sonder dat die aard van so 'n teks as verhalende teks met bepaalde verhalende eienskappe in die gedrang kom. Daarom kan 'n narratologiese benadering wat by die semio-strukturalistiese beskouinge van die klassieke narratologie begin, aangevul word met insigte uit byvoorbeeld die psigoanalise, die resepsieteorieë, dekonstruksie en die ideologiekritiek.

Om na filmtekste binne die dissipline van die narratologie te kyk, hou baie moontlikhede in.

Daar kan geëksperimenteer word met die moontlikhede van die narratologie as dissipline en dit sou die literatuurwetenskap as relevante en kontemporêr-gerigte wetenskap kon uitbou. 
* Omdat beeld en klank, lig en beweging, tegniek en ekonomiese oorweginge almal onder meer deel vorm van die moontlikhede en beperkinge van die film as kommunikasiemedium, bied die bestudering van films 'n uitstekende geleentheid tot interdissiplinêre studie. Hierin word dan aangesluit by die sterk tendens tot interdissiplinêre studie in kontemporêre akademiese aktiwiteit.

Die bestudering van films kan egter op 'n heel praktiese vlak gemotiveer word. Die film is tans sonder twyfel een van die populêrste vorms van ontspanning en vermaak. Die gevolg hiervan is dat die meeste mense (en veral studente) ongetwyfeld veel beter visueelgeletterd is as wat hulle in die literatuur of lees in die algemeen geskool is. Die konvensies van die film op wye doek word deels ook gebruik op televisie sodat mense absoluut vertroud is met 'n groot verskeidenheid vorme van visuele kommunikasie.

Die vermoede dat 'n mens met so 'n kursus in 'n behoefte gaan voorsien (juis vanweë die visuele geletterdheid en belangstelling in die visuele media by die hedendaagse student), het in die praktyk heeltemal waar geblyk te wees. Waar' $n$ mens in ' $n$ letterkundelesing net hoflike uitdrukkingloosheid of afgewende oë sien as jy studente vra om 'n verwante voorbeeld uit 'n ander literêre werk te noem, is die reaksie op 'n soortgelyke vraag oor films oorweldigend. Studente kan filmtegnieke en visuele strategieë in kunsfilms herken en in verband bring met 'n menigte voorbeelde uit die populêre films waarmee hulle hulle elke naweek (en elke week) vermaak.

Die film is nie net ' $n$ uiters effektiewe kommunikasiemedium nie, maar word soms selfs as dié kunsvorm van ons tyd beskou. As sodanig is daar haas geen buitengewone motivering nodig om die bestudering van films te regverdig nie.

\subsection{Algemene moontlikhede vir die kursus}

Wanneer films bestudeer word binne die literatuurwetenskap, moet daar natuurlik rekening gehou word met die kontemporêre en historiese kernvraagstukke van die wetenskaplike bestudering van die literatuur en van kommunikasie in die algemeen. Binne die literatuurwetenskap val die klem vanselfsprekend op die hermeneutiese en ook estetiese aspekte van films. Hoe kyk 'n mens na 'n film? Hoe funksioneer die kodes van die filmmedium? Watter tegnieke word gebruik om bepaalde betekenisse en effekte te genereer in 'n film? Watter interpretasiemoontlikhede van films kan ontgin word? Waarom is sommige films kunsfilms en ander nie? Waar lê die grense tussen massavermaak, lokettreffers en kunsfilms?

In aansluiting by die kontemporêre tendense in die literatuurwetenskap moet daar egter ook indringend aandag gegee word aan die wyer konteks van kommunikasie, soos byvoorbeeld die rol van die leser, die sosiale relevansie van films en 'n aantal verskynsels wat verband hou met intertekstualiteit.

Die bestudering van die wyer konteks van kommunikasie lei tot vrae soos: Wat is die rol van 'n bepaalde kyker in die verstaan van 'n film? Watter ideologiese kwessies kom na vore in 'n film of word deur 'n bepaalde kykervaring geaktiveer?

Komplekser vraagstukke kan ook betrek word. Is die film byvoorbeeld werklik 'n realistiese medium? Wat is die verhouding tussen film en werklikheid en wat van die 
illusionêre kwaliteit van die film? Waarom is sommige films finansieel geweldige suksesvol en ander nie - lê dit in die filmteks self of in die kykerbehoeftes op 'n bepaalde moment in tyd?

\subsection{Afbakening van die kursus}

In hierdie kursus word die terrein spesifiek beperk tot die bestudering van bepaalde films wat op romans gebaseer is. Die redes daarvoor is tweërlei. Enersyds moet 'n mens die terrein afbaken omdat die hoeveelheid stof onhanteerbaar omvangryk is, en andersyds stel dié bepaalde fokus ' $n$ mens in staat om 'n paar vlieè met een klap te slaan: die student bestudeer ' $n$ roman as verhalende teks en ook die film as verhalende teks, maar kry terselfdertyd uitgebreide blootstelling aan die teoretiese kwessies in sowel die literêre teorie as filmteorie. Die werkwyse van die narratologie figureer wel sterk, maar ander belangrike klemplasinge van die kontemporêre literatuurwetenskap en kommunikasieteorie in die algemeen word ook behandel. Teorie en praktiese teksanalise en -interpretasie (van romans en films) vul mekaar so aan.

\section{Ontwikkeling van die kursus}

Hierdie kursus, Roman en film, is met 'n oop agenda aangepak. Daar is wyd gesoek na relevante studiemateriaal aangaande die filmmedium, die verwerking van romantekste tot filmtekste en na geskikte teorie. Daar is ook gekyk na 'n groot verskeidenheid films om verantwoorde keuses te maak, sodat verteenwoordigende aspekte van die hele studieterrein gedek sou kon word. Daar word verder elke jaar ruimte gelaat sodat die studente self die lysie films kan aanvul.

Reeds uit die aanvanklike terreinverkenning het dit spoedig geblyk dat die verhouding tussen roman en film nie as eenrigting-verwerking beskou kan word nie. Dit het gou duidelik geword dat daar glad nie na romantekste en filmtekste gekyk kan word op 'n vergelykende basis nie. Daar kan veral nie evaluerend-vergelykend ten opsigte van die twee mediums gewerk word nie. In die kursus val die klem op begrip en insig in die verskillende mediums: in die praktyk kom dit daarop neer dat daar teoreties en prakties nagegaan word hoe bepaalde verhalende inligting in verskillende mediums weergegee en geïnterpreteer word.

Dit kan dan ook byna nie sterk genoeg beklemtoon word dat films nie substitute is vir romans en andersom nie. Die gebruik om films te wys omdat studente of leerlinge nie graag lees nie, omdat dit handig is om die studente of leerlinge so vinnig en maklik as moontlik met die basiese verhaallyn vertroud te maak, berus op 'n foutiewe aanname. Die film is ' $n$ ander teks in ' $n$ ander medium en moet as sodanig anders benader word. Filmstudie (wat te make het met visuele, ouditiewe en talige kommunikasie in wisselwerking) kan literatuurstudie (wat primêr met talige kommunikasie te make het) nie vervang nie en dit is selfs debatteerbaar of die twee mekaar as sodanig kan aanvul: elke teks moet as 'n teks op sigself beskou word en in sy eie reg binne sy eie kommunikatiewe raamwerk van tegnieke en strategieë ondersoek word. Dit gaan dus om kommunikasie binne verskillende semiotiese sisteme. Die verhoudinge tussen die twee soorte tekste lê op 'n meer komplekse vlak en moet nie verwar word met die 'maklike' uitweg dat 'n mens net sowel die film kan kyk wanneer jy die roman moet bestudeer nie. 
In aansluiting by die doelbewuste ontwikkeling van 'n bewussyn van die werking van die taalmedium teenoor die werking van visuele en ouditiewe kommunikasie in die filmmedium, is daar besluit om die klem te laat val op estetiese en kommunikatiewe aspekte van romans en films.

Die resultaat van hierdie verkennende ontwikkeling het die volgende benadering tot gevolg gehad:

* Die teoretiese benadering kan heel wyd as 'n semiotiese benadering beskryf word. Die film word beskou as ' $n$ meervoudige tekensisteem waarin taal sowel as klank, kleur, vorm, beeld en lig as betekenisgenererende tekens funksioneer en die roman as 'n talige tekensisteem.

* Daar word gekyk na die komplekse wisselwerking tussen die romanteks en die filmteks sodat die twee soorte tekste as intertekste by mekaar aansluit.

* Die interaksie tussen tekste en ontvangers word deurgaans as van deurslaggewende belang beskou. In die filmwese is hierdie teoretiese uitgangspunt ' $n$ heel praktiese aangeleentheid. Films kos geld en daarom is loketsyfers altyd belangrik: 'The box office is never wrong'. 'Goeie' films is meestal duur omdat goeie tegnici en toerusting duur is. Omdat geld 'n voorvereiste is vir die mak van films van gehalte, kan die geslaagdheid van die film in die praktyk nooit buite rekening gelaat word nie. Die film is in veel groter mate as die roman verbruikersgerig en dié aspek van filmmatige kommunikasie is altyd relevant.

- Die resepsie van tekste is verder van groot belang as 'n mens die sosiale relevansie van 'n teks wil bepaal. Sommige verskille tussen 'n romanteks en 'n filmteks (as doelbewuste verwerkings van die romanteks deur draaiboekskrywer of regisseur) kan herlei word na die behoeftes en smake van die filmkykende gemeenskap op 'n bepaalde historiese moment. Die filmiese verwerking van 'n roman kan in sommige gevalle gesien word as 'n weerspieëling van die behoeftes of smake van die gemeenskap en in die bemarking van die film speel die voorkeure en afkeure van die gemeenskap 'n groot rol. Sommige films en romans wil juis die selftevredenheid van die gemeenskap uitdaag en dit is baie interessant om na te gaan in hoe 'n mate daarin geslaag word.

- Die breë benadering in die kursus is intertekstueel, maar nie soos Derrida (1977:163; 1981:202) intertekstualiteit as grenslose en oneindige semiose omskryf nie. Dit gaan hier om die identifikasie van relevante intertekste wat in ' $n$ bepaalde lees- of kykervaring oormekaarskuif sodat 'n bepaalde interpretasie (wat nie die enigste of bepalende of uiteindelike interpretasie kan wees nie) gemaak kan word (vgl. Kristeva, 1980:15,36; 1986:111; Barthes, 1957:10; 1974:5).

* Die studente het 'n groot aandeel in die ontwikkeling van die kursus. Omdat studente met verskillende voorgraadse vakkombinasies en hoofvakke tot die kursus toegelaat word, kry 'n mens insette uit verskillende hoeke. So het studente in referate al die klem geplaas op psigologiese of kommunikasiekundige aspekte van films en hierdie insette is in die kursus vir volgende jaargroepe ingewerk. 


\section{Inhoud van die kursus}

\subsection{Die narratologiese model}

Ter inleiding word die studente vertroud gemaak met die basiese narratologiese model. Omdat almal nie literatuurwetenskap op voorgraadse vlak gehad het nie, moet hulle die basiese narratologiese terminologie en werkwyse leer ken en leer gebruik. Die feit dat die narratologie as basis gebruik word, word verduidelik en daar word aangetoon op welke wyse die film as 'n verhalende teks beskou kan word.

Daar word deurgaans beklemtoon dat die narratologie 'n dinamiese dissipline is en dat aanpassings in die basiese teoretiese model aangebring kan word om die tekste op ' $n$ kreatiewe wyse te interpreteer. So word die moontlikhede van die teorie ook uitgebrei (vgl. Du Plooy, 1991).

Daarna word 'n inleiding oor die semiotiek gegee, met die klem op die feit dat die semiotiek nie tot die bestudering van taaltekste beperk is nie. Uiteindelik word verduidelik hoe die film as semiotiese sisteem beskou kan word waarin verskillende tekensisteme gelyktydig werksaam is.

Die bronne wat hier gebruik word is die basies bronne van die narratologie (Bal, 1980; Rimmon-Kenan, 1983; Chatman, 1978; Du Plooy, 1986) en bronne oor die film as semiotiese sisteem (Lotman, 1976; Metz, 1974a; Metz, 1974b).

\subsection{Basiese filmteorie}

Die agtergrond van die film as kunsvorm en kommunikasiemedium word behandel met klem op die volgende aspekte:

* 'n Historiese oorsig oor die ontwikkeling van die filmwese en visuele geletterdheid word gegee. Hier word die aksent geplaas op die feit dat die film ontwikkel het uit vermaaklikheidspeletjies. Die ontwikkeling van 'n eksentrieke tydverdryf of rare vermaaklikheidsitem tot kunsvorm word nagegaan. Daar word in besonder beklemtoon dat die film vir sy ontwikkeling afhanklik is van tegnologiese moontlikhede en dat hierdie moontlikhede voortdurend nuwe filmtegnieke laat ontwikkel. Die eksperimentele aard van die film (tegnologies gesproke) sluit hierby aan. Uiteindelik word die filmwese in ' $n$ groot mate beïnvloed deur geld - films kos geld en goeie films is baie duur. Daarom moet filmmaatskappye genoeg geld maak om goeie films te kan maak. Min filmmakers kan duur eksperimente bekostig en die praktyk bepaal grootliks die soort films en die soort eksperimente wat gemaak kan word. Die bronne wat hier gebruik word, is hoofsaaklik Mast (1981), Mast en Cohen (1985) en Rhode (1976). Daar is egter geweldig baie boeke oor verskillende aspekte van die historiese ontwikkeling van die filmwese (ook in verskillende lande) beskikbaar.

* Die aard van beeldmatige kommunikasie is baie belangrik wanneer dit gaan om die interpretasie van films. Omdat beeldmatige kommunikasie pre-simboliese kommunikasie is, kan beelde nie sonder meer gelykgestel word aan woorde nie. 'One picture speaks a thousand words' is die populêre spreuk, maar dit sluit aan by die sieninge van Lacan oor hierdie soort kommunikasie en by Kristeva se siening van die pre- 
simboliese fase van die ontwikkeling van die menslike intellek en psige (vgl. ook Lotman, 1976; Metz, 1974(a); Metz 1974(b); Kristeva, 1986:93-98; Lacan, 1977:1-7; Lapsley \& Westlake, 1988).

* Basiese filmestetika word behandel sodat dinge soos die gebrek aan neutraliteit van die kamera-oog (fokalisasie in narratologiese terminologie), kleur, lig, afstand, beeldkomposisie, musiek en klank in die algemeen as betekenisvolle aspekte van die film herken kan word (Sparshott, 1985; Mast \& Cohen, 1985; Higgins, 1992; Johnson, 1989; Scheunemann, 1988; Wulff, 1988).

\subsection{Teksstudies}

Die grootste komponent van die kursus bestaan uit die bestudering van bepaalde romanen filmtekste. By elke paar tekste (roman en film) word 'n bepaalde fokus gekies sodat die student kumulatief met verskillende aspekte van die tekste te make kry.

'n Narratologiese beskrywing en analise is die beginpunt van die studie en 'n kreatiewe interpretasie van die tekste as relevante betekenisdraende en betekenisgenererende tekste die einddoel.

Die roman word gelees en bespreek. Daar word na die film gekyk en aanvanklik apart en as afsonderlik selfstandige teks bespreek. Daar word soveel moontlik gebruik gemaak van gesprekke en groepbesprekings: die studente dra self baie by tot die interpretasie van die tekste. Indien hulle die teoretiese moontlikhede goed begryp, lê elke student klem op 'n ander aspek en so kom elkeen in aanraking met ' $n$ verskeidenheid standpunte en aksente. Soos wat die jaar vorder, raak hulle toenemend vertroud met die moontlikhede van die twee mediums en kan hulle al hoe meer vrylik improviseer namate hulle verwysingsraamwerk uitbrei.

By elke filmteks is ' $n$ bepaalde fokuspunt geidentifiseer. Hiermee bedoel ek dat daar klem geplaas word op ' $n$ bepaalde aspek van die bepaalde film en van die verhouding tussen die film en die roman. Op dié manier probeer ek soveel as moontlik variasie in die kursus invoer en om so veel as moontlik aspekte van die romans en films teoreties en prakties aan te raak terwyl daar steeds deeglik gelees en gekyk en geïnterpreteer word. Om te illustreer hoe daar te werk gegaan word, gee ek 'n beknopte oorsig van die inhoud van die kursus ten opsigte van bepaalde tekste.

\section{Voorbeelde van teksstudies}

\subsection{The French Lieutenant's Woman - John Fowles}

Die aspek van dié twee tekste wat beklemtoon word, is die verskil in die aanbieding van narratiewe gegewens in die taalteks en die visuele teks.

\subsubsection{Talige en visuele tekens}

Die roman van John Fowles is 'n komplekse teks waarin veelvuldige interessante vertelstrategieë voorkom. 'n Narratologiese beskrywing en analise van die roman lewer dan gewoonlik uitgebreide resultate en meervoudige interpretasies. Die veelvuldige 
verwysings, literêr en andersins in die motto's maar ook in die vertelteks self, die kommentaar van die verteller oor skrywerskap en oor die outeursaktiwiteit asook oor die verhalende inhoud self, kompliseer nie net die verhalende gegewens nie, maar vermenigvuldig interpretatiewe moontlikhede omdat die roman so 'n uitgebreide metatekstuele vlak opbou. Die komplekse vertelstyl van die roman is ironies genoeg aanvanklik deur kritici as ' $\mathrm{n}$ probleem beskou en het baie negatiewe kommentaar ontlok. Die verteller is as lastig en inmengerig beskryf en daar is gesề dat sulke kommentaar die illusie van fiktiwiteit verbreek. Tog is dit juis hierdie verteltegniek wat die intertekstuele ruimte waarbinne die roman funksioneer, uitbrei en vergroot.

In die analise van die roman word daar gekonsentreer op die verteltegniese aspekte van fokalisasie en vertelinstansie en op die betekenisgenererende funksie van die kommentaar van die verteller en die verwysings in die outeursteks.

Die rede vir die klem op vertelstrategieê is voor die hand liggend. In die draaiboek is hierdie romangegewe op 'n buitengewoon vindingryke wyse verwerk. Die draaiboek is aanvanklik geskryf deur Harold Pinter (1982) en hierdie draaiboek is op sigself 'n interessante teks wat ontleed kan word. Pinter moes die inligting in die roman wat te make het met die kontras tussen die Victoriaanse en moderne era en die verskillende sieninge van die vrou in hierdie twee eras op 'n manier in die film inwerk. In die roman word hierdie inligting deur die kommentariënde verteller gegee, maar Pinter het dit moontlik gemaak om hierdie kontraste en ooreenkomste visueel voor te stel deur die metatekstuele aard van die film.

Die twee 'akteurs' wat die rolle van Sarah en Charles vertolk, Mike en Anna, het op die stel van die verfilming ook 'n verhouding en hierdie geëmansipeerde verhouding lewer beeldmatig (on)uitgesproke kommentaar op die Victoriaanse verhaal en andersom.

Die vertelinstansie se kommentaar is dus visueel in die film ingewerk deur van twee verhaallyne gebruik te mak. Verder is die manier waarop die oorgange tussen die moderne en Victoriaanse verhale gemaak word van groot belang. Die implisiete wedersydse kommentaar van die insidente en karakters wat deur die afwisselend Victoriaanse en moderne stories naas mekaar geplaas word, skep meervoudige interpretasiemoontlikhede. Die gekompliseerdheid van mense, die verhoudinge tussen mense, die invloed van die historiese periode waarin mense leef, word nie net deur die jukstaponerende struktuur van die film beklemtoon nie, maar ook deur die eksplisiet selfbewuste of metatekstuele aard van die film, wat by die metatekstuele aard van die roman aansluit.

Die film begin met 'n toneel op 'n filmstel: die klapbord en die grimeerdeskundige wat die laaste afronding aan die aktrise se gesig doen, maak dit duidelik dat dit hier gaan om die bewuste besigwees met die mak van 'n teks. In die roman verskyn die outeurspersoonlikheid twee keer as 'n karakter in die roman en in die film gaan dit om die maak van ' $n$ film. In die film loop die twee verhale uiteindelik inmekaar as Mike na Anna roep en haar Sarah noem.

Die belangrike ideologiese implikasies wat in die roman deur die verwysings en motto's geaktiveer word, word in die film ook deur visuele kontraste uitgebeeld. Die bediendes kyk byvoorbeeld deur die venster hoe Ernestina en Charles 'leef'. Die onoorbrugbare sosiale stratifikasie tussen Sarah en Charles word duidelik uit die plasing van die gaste in Aunt Tranter se sitkamer: Sarah is wel aanwesig, want sy is nie 'n bediende nie, maar sy 
praat nie eintlik nie, help bedien en sit buite die kring - 'n soort aanhangsel.

Dit is slegs enkele voorbeelde van hoe narratiewe inligting in die taalteks verskil van dieselfde inligting in die film.

\subsubsection{Teoretiese bespiegeling}

Die vraag ontstaan of ' $n$ film van twee uur selfs naastenby die hoeveelheid inligting kan oordra as 'n omvangryke en komplekse roman. Gee die film egter hoegenaamd die roman weer? Hoe kan die verhouding tussen die twee tekste verklaar of beskryf word?

Aanvanklik is die verwerking van die roman tot draaiboek teoreties beskryf volgens Barthes (1977b) se uiteensetting van die narratiewe struktuur van 'n verhalende teks. Volgens hierdie beskrywing bestaan 'n teks uit kardinale funksies en indisieë, respektiewelik die belangrike gebeurtenisse en die bepalende artistieke gegewens in ' $n$ teks. Ander elemente in 'n teks is die katalisators, die minder belangrike gebeurtenisse en die informatiewe, die inligting wat die teks 'n realistiese aansyn gee met inligting oor plekke en klere en ander 'werklike' gegewens.

In die verwerking van The French Lieutenant's Woman van die roman na die film is die kardinale funksies, die belangrike momente van verandering en beslissing behou en minder belangrike gebeurtenisse, die katalisators volgens Barthes se terminologie, is weggelaat. Op dieselfde wyse is sekere indisie ë, die beslissende artistieke betekenisvolle bindende elemente behou terwyl die informatiewe weggelaat kon word of in die realistiese beeld verwerk is. So is die toneel waar Charles Sarah die eerste keer op die hawehoof sien tot in detail behou - die enigmatiese gesig waarvan die uitdrukking nie peilbaar is nie, die swart mantel, wat nie net die somberheid van die figuur beklemtoon nie, maar ook die swart kap wat die gesig omraam en in skadu hou, die stormagtige see en die onherbergsaamheid van die omgewing, Charles se konvensionele gentlemanly concern en Sarah se onbevreesde uitstaar oor die stormsee is voorbeelde van sulke artistiek betekenisvolle elemente wat uiteindelik die oorkoepelende betekenis in sowel die film as die roman bepaal. Die twee tekste dra in hierdie geval dieselfde betekenis oor, maar op verskillende maniere en deur die verskillende mediums artistiek te ontgin.

Die reduksie in verhalende gegewe, van die narratiewe inligting, is by hierdie twee tekste duidelik: die groot hoeveelheid gebeurtenisse, die hoeveelheid inligting in elke beskrywing van elke karakter en selfs die aantal karakters van die roman kom nie in die film voor nie.

Die vraag ontstaan dan of die film as 'n reduksie van die roman gesien moet word?

Sommige studente glo wel dat die film 'n reduksie is van die roman, hoewel dit nie noodwendig die kwaliteit van die film bepaal nie. Ander studente het gaan nalees oor die primêre aard van beeldmatige kommunikasie (soos beskryf deur Lacan,1977:1-7 en Kristeva, 1986:93-98) en uiteindelik het ons besluit dat die vergelyking inderdaad irrelevant is.

Die film bevat, narratief gesproke, minder gegewens, maar die kompleksiteit van elke beeld vergoed daarvoor. Die detail van elke vertrek en landskap, die ligval in elke toneel, die gesigsuitdrukking van elke akteur, dra 'n groot hoeveelheid inligting oor. 
Hierby kom die klankbaan van die film - elke stemintonasie van die akteurs, die kontras tussen stemme, die toonhoogte en luidheid van woorde en geluide, en veral die musiek bring 'n verder aanvulling. Uiteindellik is daar 'n selfs sprake van oorkodering in ' $n$ film selfs as baie elemente nie raakgesien word nie, kan die film nog 'n ryk en bevredigende ervaring wees. Die appél op verskillende sintuie en die appél op intuïsie in beeldmatige kommunikasie vergoed tot ' $n$ groot mate vir die vereenvoudiging in die verhaallyn, want die essensie van die film is net so kompleks as dié van die roman.

\subsubsection{Die praktyk van filmvervaardiging}

Omdat daar oor hierdie film soveel inligting beskikbaar is, kan 'n mens hier ook mooi illustreer hoe die film 'n spanpoging is. Fowles het self vir Karel Reisz gevra om hierdie roman te verfilm. Reisz het eers etlike jare later daartoe gekom. Die roman is deur Harold Pinter verwerk, op versoek van die regisseur en die skrywer. Die draaiboek is egter weer deur Reisz aangepas tot so 'n mate dat sommige kritici praat van 'the Czech director's woman'. Die bydrae van die akteurs kan egter nooit onderskat word nie en Meryl Streep en Jeremy Irons se vertolking speel telkens ' $n$ bepalende rol in die totstandkoming van die karakters (Conradi, 1985). Voeg hierby al die tegniese elemente soos beligting, klank en kamerawerk en dit is duidelik dat 'n film 'n spanpoging is. Deur hierdie meervoudige insette kom die kompleksiteit en meerduidigheid van die filmteks tot stand, wat dit uiteindelik binne sy eie medium net so 'n ryk teks maak as die veel 'omvattender' roman (Knapp, 1985; Modern Fiction Studies, 1985, 31(1)).

\subsection{Ander tekste}

Ek gaan baie kortliks na 'n paar ander tekste verwys en aantoon watter klemplasinge gebruik word in die onderrigsituasie.

\subsubsection{The Name of the Rose - Umberto Eco}

Hierdie roman, seker een van die grootste en rykste en mees komplekse romans van die laat twintigste eeu, is op bykans alle terreine 'n ontdekkingstog vir die student: narratologies interessant en intertekstueel haas onuitputlik. Vir'n referaat oor die roman kan die student bykans enige invalshoek kies en telkens met nuwe en stimulerende gegewens vorendag kom.

\subsubsection{Die semiotiek}

In hierdie kursus word die bespreking van die boek, The Name of the Rose, voorafgegaan deur 'n inleiding oor die semiotiek as algemene studieterrein, met spesifieke verwysing na die semiotiek as literêre teorie. Daarna word die kernkonsepte van Eco se teorie bespreek: die modelleser, oop en geslote tekste, die belang van kodes, betekenis as 'n labirint of netwerk van haas oneindige semiose wat slegs deur die kontoere van kodes beperk word (Eco, 1976; Eco, 1979; Eco, 1990).

Hierdie teoretiese aksent word deurgetrek in besprekings van die verhaalmatige uitwerk van die teorie van tekens. In die roman is daar uitvoerige ontginning van tekens soos die 
biblioteek as teken/metafoor vir betekenis, maar ook in die klein detail is daar die voortdurende ontginning van beeide en sake as tekens met die vermoë om telkens 'n uitgebreide en uitgestelde proses van semiose te genereer. In die film word dieselfde filmmatig gedoen: elke gesig van elke karakter is 'n teken vir 'n hele verhaal. Daar is die askeet (Ubertino) met sy skedelhoof, die fanatikus (Bernardo Gui) met sy ongenaakbare gesig, die verwyfde esteet en marionet (die ab), die verwaarloosde wanskapige en half vertraagde mens, die onvermydelike sondebok en slagoffer, in wie onskuld en boosheid ononderskeibaar en onskeibaar saamgroei (Salvatore), die ironiese intellektueel en wetenskaplike (William) en die sagte ongevormde jong seun (Adso), in wie se gesig die ontstellende gebeure soos in 'n spieël gereflekteer word.

\subsubsection{Ontvangersgerigtheid}

Eco se kennis van en vertroudheid met kommunikasiestrategieë word in sowel die roman as die film benut. Van sy roman sê hy in Reflections on The Name of the Rose (1985) dat hy sy lesers vir die roman keur met die eerste (baie moeilike) honderd bladsye van die roman: die leser wat hierdie bladsye trotseer, is die leser wat Eco wil hê om die roman te lees. Op dieselfde manier is die film op 'n bepaalde gehoor gerig, nie die leser wat in esoteriese gesprekke en filosofieë geïnteresseerd is soos by die roman nie, maar die filmteaterganger. Die film is gemaak vir 'n ander medium, maar ook vir 'n ander groep ontvangers. En Eco weet dat suksesvolle kommunikasie afhanklik is van die kunstenaar se ontvangersbewussyn: die film is dus meer toeganklik, al is dit nog glad nie populêr nie. Die verandering aan die slot van die verhaal in die film kan ook waarskynlik toegeskryf word aan 'n poging om die fliekganger effens te sus, waar die roman se slot juis 'oop' en intens ontstellend kan wees.

In hierdie geval word die roman en die film elk ondersoek as 'n teks gerig op 'n bepaalde ontvangersgroep, en omdat die beskouinge van die semiotikus sterk deurwerk, word daar gekyk hoe die verskillende soorte tekenstelsels funksioneer om betekenis te genereer.

\subsubsection{Kontemporêre relevansic}

In die roman en die film The Name of the Rose is daar die ontstellende parallel tussen die Middeleeue en die laat twinigste eeu: die omvang van sosiale polarisasie, die interverweefdheid van die stelsels wat die nasionale en internasionale infrastruktuur beheer en staande hou, die onontkombare ineenstorting van stelsels wat te groot en te lomp geword het (Eco, 1984).

Die roman is ' $n$ web van intertekste wat die probleme van die Middeleeuse gemeenskap op so 'n wyse aan die orde stel dat die kontemporêre problematiek ook daarin aangeraak word (Eco,1984). Die komplekse hantering en ontwikkeling van religieuse kwessies is byvoorbeeld sodanig dat dit net so in die kontemporêre arena sou kon pas. Daar is die fundamentaliste, die fanatici, die naiewes, die slagoffers en magsoekers - almal agente in die religieuse bedryf, toe net soos vandag. Die stryd tussen wetenskap en geloof word tans met net soveel energie gevoer as in die 14 de eeu. Net soos vandag was daar die debatte tussen die Nominaliste (die Middeleeuse dekonstruksioniste) en die logosentriste, wat geloof in woorde vind.

Die essensie van sulke tematiese kwessies word in die film beeldmatig voorgestel - dus minder kompleks (filosofies gesproke), maar in die hiperrealistiese detail skokkend direk 
en treffend.

\subsubsection{Babette's Feast - Isak Dinesen (Karen Blixen)}

In teenstelling met die vorige twee voorbeelde kan daar in 'n ondersoek na hierdie kortverhaal en film gekyk word hoe 'n relatief eenvoudige kortverhaal tot 'n film van dieselfde omvang en trefkrag as die vorige twee omgewerk is. Waar in die vorige twee voorbeelde die romans gekondenseer moes word tot die essensie, word in Babette's Feast die fynste en mees subtiele suggesties van die kortverhaal, in die film as visuele voorstellinge uitgewerk. Hierdie film is 'n meesterstuk wat in sy eteriese visuele kwaliteit iets van die broosheid en beperkinge van religieuse belewenis en menslike emosie vasvang.

\subsubsection{Kuns en religie}

Vir die bespreking van hierdie film word gekonsentreer op die temas van religie en kuns en die komplekse verhouding tussen hierdie twee terreine. Op verstommende wyse leen hierdie oënskynlik eenvoudige tekste (kortverhaal en film) hulle tot gesprekke oor religie, verstarde religie, die bevrydende bevrugtende werking van die kuns en die krag van die liefde in sowel kuns as religie. Die romantiese, byna naïewe siening van kuns wat 'n mens hier vind, word in die verhalende gegewens op oortuigende wyse geldig gemaak: die visioenêre kwaliteit van alle groot kunswerke, die metafisiese dimensie van die kunstenaarsaktiwiteit word aards werklik en aanvaarbaar in Babette se liefdesmaaltyd. Die estetiese kwaliteit van die gewoonste dinge soos die kos vir die siekes en oues word deur die majesteitlike ete terugwerkend aangetoon en die bewussyn van so 'n estetiese dimensie in die alledaagse is die essensie van lewenskwaliteit.

Uiteindelik kan selfs 'n religieuse vernuwing bewerkstellig word deur die gawe van die kunstenaar. Hierdie gawe het ironies genoeg sowel 'n selfsugtige as onselfsugtige dimensie (dit verskaf Babette vreugde om die gaste koninklik te onthaal), maar iewers oorstyg die talent menslike beperkinge.

\subsubsection{Kleur as 'n visuele teken}

Kleur speel 'n baie belangrike rol in die filmkuns. Die aanvanklike strewe na realistiese kleur is haas vervolmaak en tans is 'n spel met kleur 'n sterk filmtegniek.

Babette's Feast is wat kleur betref besonder sober, selfs vaal. Die film het min kleur en daarom is dit by uitstek geskik om die funksionele gebruik van kleur te bespreek (Wulff, 1988). Die afwesigheid van kleur, maak kleurkontraste en die potensiële betekenisdraende funksies van kleur soveel meer relevant. Die afwesigheid van visuele aanskoulikheid, maak dit moontlik om elke skoot as 'n soort fotostudie te beskou. Die film het 'n sterk beeldmatige karakter, want elke gesig is 'n kamee, wat as 'n portretstudie telkens boekdele vertel van ongesegde en selfs onsêbare dinge.

\section{Verdere moontlikhede}

In 'n kursus soos hierdie kan baie verskillende moontlikhede ontgin word. 'n Mens kan interdissiplinêr werk en so die relevansie van die kursus sterk uitbou. 
* Die resepsie van populêre films is 'n moontlike ondersoekterrein, waaruit belangrike afleidings oor die tendense en behoeftes in die kontemporêre gemeenskap gemaak kan word.

* Die aanpassing van die narratiewe gegewens in bepaalde romans in die filmweergawes is dikwels markgerig of ideologies bepaal (byvoorbeeld in die geval van die TV-verwerking van Verspeelde lente van J. van Melle en die verkorting van die TV-reeks van vier uur, The Fourth Reich tot 'n film van 90 minute).

- Die tegniek van montage vanaf die werk van Eisenstein (1985) tot die kontemporêre gebruik daarvan is ' $n$ besonder boeiende aspek van filmkommunikasie. Waar montage aanvanklik met eksplisiete ideologiese en politieke motiewe gebruik is, is redigering tans 'n aanvaarde algemene tegniek van die filmkuns. In 'n film soos Fatal Attraction word redigering baie effektief gebruik om spanning (tot die histeriese toe) op te bou. Wanneer die ongebalanseerde vrou haar minnaar se kind ontvoer, word skote van die vrou en die kind se rit op die rollercoaster afgewissel met skote van die ma wat die kind soek. Die histeriese opgewonderheid en ekstase van die twee wat afgrond op afgrond op die spoor van die rollercoaster trotseer en die histeriese angs van die bekommerde ma bewerk 'n algemene histerie van spanning by die kyker.

* Terwyl die sosiale en politieke relevansie van sommige films ideale studiemateriaal bied, is daar ook aanverwante verskynsels wat baie interessant is. So kan 'n bepaalde soort intertekstualiteit ondersoek word aan die hand van die geval The Phantom of the Opera. Van hierdie roman van Gaston Leroux uit 1911 bestaan daar verskeie versies in stomfilms en klankfilms en dramas. Telkens is die Spook anders voorgestel en die aard van sy geskendheid anders verklaar. Vreemd genoeg bereik nie een van hierdie versies werklik die vlak van artistieke voortreflikheid nie. Daar bestaan ook 'n TV-weergawe wat taamlik kitscherig en romanties is. Dit is egter asof die storie self so boeiend is dat dit telkens weer as inspirasie dien vir 'n volgende verwerking, al het almal al vir Gaston Leroux, die oorspronklike skrywer wat 'n Franse joernalis en skrywer van baie populêre romans was, vergeet (Perry, 1989).

Die musiekspel van Andrew Lloydd Webber (Perry, 1989:137 e.v.) is waarskynlik die vorm waarin Leroux se verhaal uiteindelik artistieke statuur kry. Tans is dit nie op film beskikbaar nie, maar daar bestaan wel drie musiekvideos van uittreksels uit die musiekspel en die klankbaan is natuurlik beskikbaar. Net soos die Don Juanlegende, bestaan daar verskillende versies van dieselfde verhaal, maar hier maak die musiek die uiteindelike verskil. 


\section{Ten slotte}

Die gesamentlike bestudering van films en romans is besonder stimulerend vir dosent en student. In so 'n kursus kan 'n baie groot aantal kwessies gemaklik en op besonder aangename wyse betrek word: van die suiwer estetiese tot die absoluut pragmatiese en selfs tot die ideologies en polities relevante. In die teenoormekaarstelling van die twee mediums is dit ook asof elkeen op sigself duideliker raakgesien word: die roman as taalteks is onderhewig aan die beperkinge van taal, maar die tempo word deur die leser bepaal en die vrye spel van verbeelding kan volgens die leser se willekeur sy loop neem. Die film daarenteen is reeds ' $n$ interpretasie van verhalende gegewens omdat die voorkoms van karakters en plekke en die atmosfeer reeds vasgestel is. Vindingryke kamerategniek, beligting, die subtiele en suggestiewe gebruik van die klankbaan kompliseer egter die blote beeld tot so 'n mate dat veelvuldige interpretasiemoontlikhede weer eens ontstaan.

Die feit bly staan dat die film een van die belangrikste mediums van ons tyd is en dat die bestudering daarvan nie net aangenaam is nie, maar ook noodsaaklik omdat ons studente kinders van hulle tyd is en moet wees. Dit impliseer dat hulle die moontlikhede en beperkinge van die kunsvorme van hulle eie tyd so goed as moontlik moet verstaan.

\section{Bibliografie en leeslys}

\subsection{Primêre bronne:}

Dinesen, lsak (Blixen, Karen) 1986. Babcttc's Fcast. In: Anecdotes of Destiny. London : Penguin. p. 23-70.

Eco, Umberto. 1983. The Name of the Rose. London : Secker \& Warburg.

Fowles, John. 1987. The French Lieutenan's Woman. London : Pan Books.

Leroux, Gaston. s.j.(1911?) The Phaniom of the Opera. London : Reader's Library.

Lloyd Webber, Andrew. 1989. The Phantom of the Opera. The libretlo. (Lyrics by Charles Hart and Richard Stilgoe). London : The Really Uscful Group P.L.C. In: Perry, George. The Complete Phantom of the Opera. London : Pavilion Books Limited.

Mulisch, Harry. 1988. De aanslag. Amstcrdam : De Berigc Bij.

Pinter, Harold. 1982. The French Lieutenant's Woman, and Other Screenplays. London : Mcthuen.

\subsection{Films:}

Annaud, Jean-J acques. 1986. The Name of the Rose. West-Germany, Italy, France : Neue Constantin Film Produktion.

Axel, Gabriel. 1987. Babette's Feast. Denmark : S-A Panorama Film International.

Lyne, Adrian. 1987. Fatal Auraction. VSA : Paramount Pictures.

Rademakers, Fons. 1986. De Aanslag. Nederland : Cannon Group.

Van Rcnsburg, Manie. 1984. Verspeelde lcnte. Suid-Afrika : Visio Filmproduksies.

Van Rensburg, Manic. 1992. The Founh Reich. Suid-Afrika : Zastron. (Hierdic inskrywing verwys na dic TV-rccks.)

Reisz, Karl. 1981. The French Licutenan's Woman. Britain : United Artists.

Richardson, Tony. s.j. The Phantom of the Opera. VSA : Sabac/Sherick Productions. (TV mini-recks.)

\subsection{Teoretiese bronne:}

\subsubsection{Narratologie:}

Bal, Miekc. 1980. De theorie van verellen en verhalen. Muiderberg : Coutinho.

Barthes, Roland. 1957. Mythologies. Paris : Editions du Seuil. 
Barthes, Roland. 1974. $S / Z$. New York : Hill and Wang.

Barthes, Roland. 1977a. Image - Music - Text. Glasgow : Fontana/Collins.

Barthes, Roland. 1977b. Introduction to the Structural Analysis of Narratives. In: Barthes, R. Image Music-Text. Glasgow : Fontana/Collins. p. 79-124.

Berendsen, M. 1984. The Teller and the Observer: Narrations and Focalization in Narrative Texts. Style, 18(2):140-158, Spring.

Chatman, Seymour. 1978. Story and Discourse. Ithaca : Cornell University Press.

Derrida, Jacques. 1977. Of Grammatology. Baltimore : Johns Hopkins University Press.

Derrida, Jacques. 1981. Dissemination. London : The Athlone Press.

Du Plooy, Heilna. 1986. Verhaalteorie in die twintigste eeu. Durban : Butterworth.

Du Plooy, Heilna. 1989. Genre, parodic en vernuwing in die werk van Etienne Leroux. Acta Academica, 21(1):99-111, Maart.

Du Plooy, Heilna. 1991. Die kreatiewe gebruik van die narratologic in die literatuuronderrig. Tydskrif vir Litcratuunwetchskap, 7(3/4):252-262. Descmber.

Du Plooy, Hcilna. 1992. Ruimte in 'n verhaal. In: Stecnberg, D.H.S. \& Du Plessis, Hans. Skryfateljee. Prctoria : Van Schaik. p. 99-105.

Eco, Umberto. 1976. A Theory of Semiotics. Bloomington : Indiana University Press.

Eco, Umberto. 1979. The Role of the Reader. Bloomington : Indiana University Press.

Eco, Umberto. 1985. Reflections on The Name of the Rose. London : Seckers \& Warburg.

Eco, Umberto. 1990. The Limils of Interpretation. Bloomington : Indiana University Press.

Fowler, A. 1985. Kinds of Literature. Oxford : Clarendon Press.

Kristeva, Julia. 1980. Desire in Langrage. New York : Columbia University Press.

Kristcva, Julia. 1986. Revolution in Poctic Language. In: Moi, Toril. The Kristeva Reader. Oxford : Basil Blackwell. p. 89-136.

Lacan, Jacques, 1977. Ecrils. A Selection. (Translated by Alan Sheridan.) New York : W.W. In: Norton \& Company.

Morgan, Thais. 1989. Is There an Intertext in This Text? Literary and Interdisciplinary Approaches to Intertextuality. Style 23(2):1-40. Summer.

Prince, G. 1982. Narratology. The Fonn and Functioning of Narative. New York : Mouton.

Rimmon-Kenan, Shlomith. 1983. Narrative Fiction: Contemporary Poetics. London : Methuen.

\subsubsection{Filmteorie:}

Bluestone, R. 1985. Limits of the Novel and the Film. In: Mast, G. \& Cohen, M. Film Thecry and Criticism. New York : Oxford University Press. p. 381-389.

Branigan, E.R. 1984. Point of View in the Cinema. Berlin : Mouton.

Eiscnstein, Sergci. 1974. Three Films: Batlleship Potemkin, October and Alexander Nevsky. (Edited by Jay Leyda, translated by Diana Matias.) London : Lorrimer Publishing.

Eisenstein, Sergei. 1985. The Cinematographic Principle and the Ideogram. A Dialectic Approach to Film Form. In: Mast, G. \& Cohen, M. Film Theory and Criticism. New York : Oxford University Press. p. 90-123.

Higgins, John. 1992. The Politics of Film Pleasure. New Contrast, 77(20)1:38-42.

Johnson, William. 1989. Sound and Image. A Further Hearing. Film Quarerly, 43(1):24-35, Fall.

Lapsley, R. \& Westlake, M. 1988. Film Theory: An Introduction. New York : Manchester University Press.

Lotman, Jurij. 1976. Semiotics of Cinema. Ann Arbor : University of Michigan Press.

Mast, G. \& Cohen, M. 1985. Film Theory and Criticism. New York : Oxford University Press.

Mast, Gerald. 1981. A Short History of the Movies. 3rd Edition. Indianapolis : Bobbs-Merrill Educational Publishing.

Metz, Christian. 1974a. Langiage and Cinema. The Hague : Mouton.

Met7, Christian. 1974b. Film Language. A Semiotics of the Cinema. New York : Oxford University Press.

Rhode, E. 1976. A History of the Cinema. London : Allen Lane.

Scheunemann, Dictrich. 1988. Montage in Theatre and Film. Obscrvations on Eisenstein and Brecht. Kodikas/Code Ars Semiotica, 11(3/4):251-272.

Scholes, Robert. 1985. Narration and Narrativity in Film. In: Mast, G. \& Cohen, M. Film Theory and Criticism. New York : Oxford University Press. p. 390-410.

Sparshott, F.E. 1985. Basic Film Aesthetics. In: Mast, G. \& Cohen, M. Film Theory and Criticism. New 
York : Oxford University Press. p. 284-304.

Wulf, Hans J. 1988. Die Signikativen Funktionen der Farben im Film. Kodikas, 11(3/4):363-376.

\subsection{Sekondêre bronne:}

Barnum, Carol M. 1985. An Interview with John Fowles. Modem Fiction Studies, 31(1):187-203, Spring. Bzzletin 141, December 1986. (Uitgawe gewy aan The Name of the Rose)

Conradi, PJ. 1985. The French Lieutenant's Woman. Novel, Screenplay, Film. Critical Quarterty, 24(1):41-57.

Dipple, Elizabeth. 1988. A Novel which is a Machine for Generating Interpretations. In: Dipple, E. The Unresolvable Plor. New York : Routledge. p. 117-139.

Eco, Umberto. 1984. De Nieuwe Middeleeuwen. Nieuw Wereld Tijdschrif, 1(6):47-58, December.

Eco, Umberto. Vir referate oor The Name of the Rose gebruik ons 'n lys bronne uit die databasis van die MLA wat bestaan uit meer as 100 bronne (baie daarvan is nie in SA beskikbaar nie).

Knapp, Shoshana. 1985. The Transformation of a Pinter Screenplay: Freedom and Calculators in The French Lieutenant's Woman. Modem Drama, XXVIII(1):55-70, March.

Modern Fiction Studies. 1985. 31(1). (Uitgawe gewy aan die werk van John Fowles)

Nelles, W. 1984. Problems for Narrative Theory: The French Lieutenant's Woman. Style, 18(2):207-216, Spring.

Perry, George. 1989. The Complete Phantom of the Opera. London : Pavilion Books Limited.

Whall, Tony. 1982. Karel Reisz's The French Lieutenant's Woman: Only the name remains the same. Literature/Film Quanerly, 10(2):75-81.

\section{Potchefstroomse Universiteit vir CHO}

